\title{
市販冷蔵鮮魚介類の酵母による污染
}

\author{
(昭和 54 年 10 月 1 日受理)
}

小畠満子* 倉田浩*

\section{Yeast Contamination of Chilled Raw Seafoods}

\section{Michiko Kobatake and Hiroshi Kurata}

(National Institute of Hygienic Sciences: 18-1, Kamiyoga 1-chome, Setagaya-ku, Tokyo)

\begin{abstract}
Microbiological examination of chilled roe of sea urchin (Namauni; Heriocidaris spp., etc., 20 samples), sliced raw tuna (Maguro sashimi; Thunnus spp., etc., 20 samples) and the foot of the hen clam (Bakagai sashimi; Mactra spp., 17 samples) was carried out to examine the microflora, especially the yeasts. The samples were collected from retail markets by official food examiners and investigated by the official microbiological methods. Counts of bacteria, yeasts and fungi in the samples of roe of sea urchin ranged from $10^{3}$ to $10^{7}, 10^{2}$ to $10^{7}$ and below $10^{4}$ per gram, respectively. Counts of bacteria, yeasts and fungi in the samples of sliced raw tuna and the foot of the hen clam were found to range from $10^{3}$ to $10^{6}, 10^{1}$ to $10^{4}$ and $10^{4}$ per gram, respectively.

In the three kinds of seafood samples, yeasts were found to be the second largest microbial group and the predominant species were asporogenous yeasts such as Rhodotorula (R. glutinis, R. rubra, R. pallida), Candida (C. guilliermondii, C. humicola, C. lipolytica, C. parapsilosis, C. zeylanoides), Trichosporon (Tr. cutaneum, Tr. pullulans, Tr. variabile) and Cryptococcus (Cr. albidus, Cr. infirmo-miniatus, Cr. laurentii, Cr. macerans). Trichosporon cutaneum, a species of opportunistic pathogen, was isolated from $45 \%$ of the samples of sliced raw tuna. In all the samples tested, the main bacterial genera were Pseudomonas, Corynebacterium, Micrococcus, Staphylococcus, etc., and representative fungal genera were Penicillium, Phoma, Fusarium, Mucor, etc.

Psychrotrophic organisms grown within 2 weeks at $5^{\circ} \mathrm{C}$ accounted for $94.6 \%$ of the total yeast cultures and $55.0 \%$ of the total fungal cultures isolated from the seafood samples.
\end{abstract}

(Received October 1, 1979)

\section{緒言}

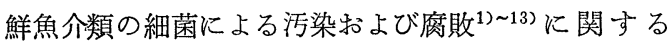
研究は多い, しかし酵母に関する研究は, 細菌のそれに 比較すると極めて少い。古く, 1894 年に Fischer ${ }^{14)}$ は 海水中のミクロフローラを研究し, 海水には酵母が広く 分布していることを最初に発表した. その後, 1920 年に なって, Hunter ${ }^{15)}$ は海水中の生カキから Rhodotorula を分離し, 1939 年には Snow ら ${ }^{16)}$ が漁獲直後の新鮮な サケに酵母が存在していることを報告した，以来，魚介 類に打ける酵母フローラの研究は急速に進展し, Phaff ${ }^{17)}$ らは小エビの, Ross ら ${ }^{18)}$ はサバ, タラなど 16 種類の 海産魚の酵母フローラを明らかにした。 また Eklund ${ }^{19)}$

* 国立衛生試験所：東京都世田谷区上用賀 1-18-1
らは, カ二肉に ${ }^{60} \mathrm{Co}-\gamma$ 線照射を行った場合, 細菌の生 育が抑制され，その反面酵母が優勢になることを報告し

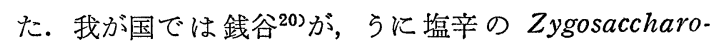
myces 属による異常発酵について研究している. 福島 ら ${ }^{211}$ は, 変敗かまぼこのネトの部分から多数の酵母を分 離し, これらのらら Candida, Trichosporon, Rhodotorula をかまぼこに接種して，陽性の成績を得ている. また，駒形ら ${ }^{22)}$ は冷凍サヶから真性低温性の Candida を分離し，酵母が冷凍食品の変敗に関与する可能性につ いて示唆した.このように，水産食品の酵母に関する食 品衛生学的な問題が提起されてきたが, 冷蔵鮮魚介類に ついて酵母, 細菌, 系状菌のミクロフローラ全体から污 染の実態をは握した調査は，まだなされていない。 
Table 1. Chilled Raw Seafoods Used for Microbiological Examination

\begin{tabular}{|c|c|c|c|c|}
\hline Japanese name & English name & Scientific name & $\begin{array}{l}\text { Fishing } \\
\text { ground }\end{array}$ & $\begin{array}{l}\text { No. of } \\
\text { Sample }\end{array}$ \\
\hline $\begin{array}{l}\text { (Nama uni) } \\
\text { Murasaki uni } \\
\text { Bafun uni }\end{array}$ & $\begin{array}{l}\text { (Roe of sea urchin) } \\
\text { Purple sea urchin } \\
\text { Green urchin }\end{array}$ & $\begin{array}{l}\text { Heriocidaris crassispina } \\
\text { Strongilocentrotus pulcherrimus }\end{array}$ & $\begin{array}{l}\text { Alaska } \\
\text { Korea } \\
\text { Japan }\end{array}$ & 20 \\
\hline $\begin{array}{l}\text { (Maguro sashimi) } \\
\text { Honmaguro } \\
\text { Mebachimaguro } \\
\text { Kiwadamaguro }\end{array}$ & $\begin{array}{l}\text { (Slice of raw tuna) } \\
\text { Bluefin tuna } \\
\text { Big-eyed tuna } \\
\text { yellowfin tuna }\end{array}$ & $\begin{array}{l}\text { Thunnus thynus } \\
\text { Parathunnus sibi } \\
\text { Neothunnus albacora }\end{array}$ & Unknown & 20 \\
\hline $\begin{array}{l}\text { (Shitakiri) } \\
\text { Bakagai }\end{array}$ & $\begin{array}{l}\text { (Foot of hen clam) } \\
\text { Hen clam }\end{array}$ & Mactra sulcataria & $\begin{array}{l}\text { Korea } \\
\text { Japan }\end{array}$ & 17 \\
\hline
\end{tabular}

そこで著者らは，生ウニ, マグロ刺身, バカガイ刺身を 調査対象に選び, 試料中の酵母, 細菌, 糸状菌の生菌数 を測定した後, これら 3 種微生物群の出現頻度を調べ, 分離酵母は菌種のレベルまで, 細菌と系状菌は菌属のレ ベルまで同定し，酵母を中心に試料中の微生物污染状況 を調査した，さらに分離微生物の低温での育成について も検討を行った.

\section{実験材料ならびに方法}

\section{試料}

韓国，アラスカ，北海道，宮城県産の生ウ $=20$, 韓 国, 北海道，千葉県，香川県産のバカガイ刺身 17 (舌切 10，アオヤギ 7)，漁獲水域不明のマグロ刺身 20 (ホン マグロ 12 , メバチマグロ 7, キワダマグロ 1) 合計 57 試料の鮮魚介類を供試試料とし, Table 1 に示した. こ れらの試料は 1976 年 9 月下旬に東京, 千葉, 神奈川 3 都県の卸市場, 百貨店, スーパーマーケット, 水産食 品店などから収集し，当日中に試験を行った．漁獲後の 経過日数と試料採取時の保管温度を Table 2 に示した。

\section{方 法 \\ 1. 生菌数測定 \\ 2. 微生物の分離 \\ 3. 微生物の同定 \\ 4. 分離酵母および糸状菌の生育温度試験}

以上は前報23) と同様に行った。

\section{実 験 結 果}

\section{1. 生菌数測定}

試料 $1 \mathrm{~g}$ 当たりの酵母数と一般細菌数の測定結果を Table 2 に, 系状菌数の測定結果を Table 6 に示した. これらの生菌数測定值を $10^{1}$ 以下, $10^{1} \sim 10^{3}, 10^{4} \sim 10^{5}$, $10^{6} \sim 10^{7}$ の 4 段階のオーダーに分け，各オーダーに拈け る試料の出現頻度を Table 3 に示した.

生ウ 20 試料の試料採取時における保管温度は,

Table 2 に示したよらに, 注 $10 \sim 15^{\circ}$ と比較的高く,
一般細菌数が $10^{4} \sim 10^{7}$ を示す試料は 12 試料 (60\%) で あった．酵母数が $10^{4}$ 〜 $10^{7}$ を示す試料は $5^{\circ}$ および $25^{\circ}$ 培養で,それぞれ 13 試料 (65\%), 15 試料 $(75 \%)$ であ り,生ウニでは酵母が細菌よりやや優勢な発育を示した. 系状菌は $25^{\circ}$ 培養の 1 試料に $10^{4}$ の高い污染度のもの が認められた。

マグロ刺身（以下マグロと略記） 20 試料の保管温度は 生ウニよりは低く，1 試料を除いては $10^{\circ}$ 以下であり, この中には冷凍状態のものが 4 試料認められた. 一般細 菌数の幅は狭く, 全試料が $10^{4} \sim 10^{5}$ の範囲にあった. 酵母数は生ウニよりは低く, $10^{4} \sim 10^{5}$ のものが $25^{\circ}$ 培着 で 4 試料 $(20 \%), 10^{1} \sim 10^{3}$ のものが 15 試料 $(75 \%)$ で あった. 系状菌数は $10^{2}$ 以下であった.

バカガイ刺身 (以下バカガイと略記) 17 試料の保管温 度は 4 試料を除いては $10^{\circ}$ 以下であった. 生菌数は生ウ ニ，マグロと比較した場合，全般的に低く，一般細菌数は $10^{4} \sim 10^{5}$ のものが 11 試料 $(60 \%)$, 酵母数は $10^{1} \sim 10^{3}$ のものが $5^{\circ}$ と $25^{\circ}$ 培養でそれぞれ 16 試料 $(94 \%)$, 15 試料 $(88 \%)$ であった。系状菌数は $10^{2}$ 以下であった.

\section{2. 微生物の分離}

生ウ二から酵母 104 株, 系状菌 37 株, 細菌 36 株, マグロから，それぞれ 91 株, 23 株, 34 株, バカガイ から，それぞれ 57 株，39 株，33 株を分離した。

\section{3. 微生物分布の概要}

冷蔵鮮魚介類に抢汀る酵母・細菌・糸状菌の 3 種微生 物群の出現頻度を Table 4 に示した.

生ウニでは，酵母は細菌と同様に全試料から検出され た. 糸状菌は $25^{\circ}$ 培養では 13 試料 $(65 \%)$ から検出さ れ，かなり高い出現頻度を示した.

マグロ 20 試料のらち, 酵母は $5^{\circ}$ と $25^{\circ}$ 培養でそれ ぞれ $16(80 \%), 19(95 \%)$ 試料から検出され, 細菌に次 いだ. 系状菌は $25^{\circ}$ 培養の場合, 約半数の試料から検出 された。 
Table 2. Microbial Counts of Chilled Seafoods Incubated at 5,25 and $35^{\circ} \mathrm{C}$

\begin{tabular}{|c|c|c|c|c|c|c|}
\hline & \multirow{2}{*}{$\begin{array}{l}\text { Sample } \\
\text { number }\end{array}$} & \multirow{2}{*}{$\underset{\left({ }^{\circ} \mathrm{C}\right)}{\text { Temp. }}{ }^{\mathrm{c})}$} & \multirow{2}{*}{$\begin{array}{l}\text { Days after } \\
\text { fishing }\end{array}$} & \multicolumn{2}{|c|}{ Yeast counts per gram at } & \multirow{2}{*}{$\frac{\begin{array}{c}\text { Bacterial counts } \\
\text { per gram at }\end{array}}{35^{\circ} \mathrm{C}}$} \\
\hline & & & & $5^{\circ} \mathrm{C}$ & $25^{\circ} \mathrm{C}$ & \\
\hline 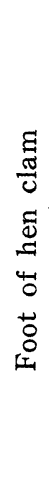 & $\begin{array}{l}A-1^{a)} \\
A-2^{a)} \\
A-3 \\
A-4^{a)} \\
A-5^{a)} \\
A-6^{a)} \\
A-7^{a)} \\
A-8^{a)} \\
A-9^{a)} \\
A-10^{a)} \\
A-11 \\
A-12^{a)} \\
A-13^{a)} \\
A-14^{a)} \\
A-15^{a} \\
A-16^{a)} \\
A-17^{2}\end{array}$ & $\begin{array}{r}7 \\
15 \\
15 \\
0-4 \\
5 \\
8 \\
8 \\
10 \\
10 \\
15 \\
\text { Ice } \\
\text { Ice } \\
\text { Ice } \\
\text { Ice } \\
\text { Ice } \\
17 \\
\text { Ice }\end{array}$ & $\begin{array}{l}2 \\
2 \\
2 \\
-{ }^{\mathrm{b})} \\
3 \\
2 \\
3 \\
3 \\
3 \\
2 \\
3 \\
3 \\
2 \\
2 \\
2 \\
3 \\
3\end{array}$ & $\begin{array}{l}3.9 \times 10^{2} \\
7.5 \times 10^{2} \\
3.6 \times 10^{2} \\
1.0 \times 10^{2} \\
2.0 \times 10^{2} \\
2.9 \times 10^{3} \\
1.7 \times 10^{3} \\
4.2 \times 10^{2} \\
3.0 \times 10^{2} \\
5.0 \times 10^{2} \\
5.0 \times 10^{1} \\
2.0 \times 10^{1} \\
1.9 \times 10^{2} \\
1.0 \times 10^{1} \\
<10 \\
1.0 \times 10^{1} \\
1.1 \times 10^{2}\end{array}$ & $\begin{array}{l}2.0 \times 10^{2} \\
6.0 \times 10^{2} \\
1.8 \times 10^{3} \\
2.0 \times 10^{2} \\
5.0 \times 10^{1} \\
4.7 \times 10^{3} \\
1.5 \times 10^{2} \\
3.0 \times 10^{2} \\
6.0 \times 10^{2} \\
2.0 \times 10^{2} \\
1.0 \times 10^{2} \\
2.1 \times 10^{2} \\
1.2 \times 10^{2} \\
<10 \\
<10 \\
2.3 \times 10^{1} \\
1.0 \times 10^{2}\end{array}$ & $\begin{array}{l}3.1 \times 10^{4} \\
4.5 \times 10^{4} \\
6.2 \times 10^{4} \\
4.1 \times 10^{4} \\
2.4 \times 10^{4} \\
5.8 \times 10^{4} \\
3.2 \times 10^{4} \\
1.0 \times 10^{6} \\
8.2 \times 10^{3} \\
1.4 \times 10^{5} \\
1.8 \times 10^{4} \\
7.5 \times 10^{3} \\
3.8 \times 10^{3} \\
2.5 \times 10^{4} \\
1.8 \times 10^{3} \\
1.2 \times 10^{4} \\
5.9 \times 10^{3}\end{array}$ \\
\hline 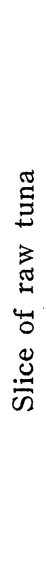 & $\begin{array}{l}M-1^{\text {a) }} \\
M-2^{\text {a) }} \\
M-3 \\
M-4 \\
M-5 \\
M-6 \\
M-7 \\
M-8 \\
M-9 \\
M-10^{\text {a) }} \\
M-11^{\text {a }} \\
M-12 \\
M-13^{\text {a) }} \\
M-14^{\text {a) }} \\
M-15 \\
M-16^{\text {a) }} \\
M-17 \\
M-18^{\text {a) }} \\
M-19^{\text {a) }} \\
M-20\end{array}$ & $\begin{array}{r}6 \\
3 \\
0 \\
2-9 \\
3 \\
6 \\
-6 \\
-10 \\
\text { Ice } \\
6 \\
5 \\
17 \\
-10 \\
6 \\
10 \\
- \\
4 \\
0 \\
-5\end{array}$ & 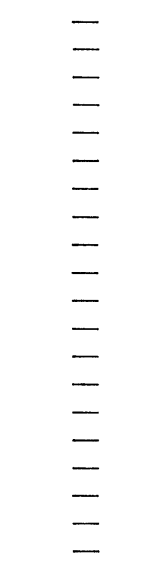 & $\begin{array}{l}\text { 5. } 0 \times 10^{1} \\
2.0 \times 10^{1} \\
<10 \\
<10 \\
\text { 3. } 0 \times 10^{2} \\
2.6 \times 10^{2} \\
9.0 \times 10^{2} \\
2.9 \times 10^{3} \\
\text { 3. } 6 \times 10^{2} \\
1.8 \times 10^{4} \\
<10 \\
1.0 \times 10^{2} \\
1.0 \times 10^{2} \\
1.6 \times 10^{2} \\
<10 \\
1.0 \times 10^{3} \\
2.8 \times 10^{3} \\
1.0 \times 10^{3} \\
4.0 \times 10^{3} \\
1.1 \times 10^{4}\end{array}$ & $\begin{array}{c}<10 \\
7.0 \times 10^{1} \\
1.3 \times 10^{3} \\
4.2 \times 10^{3} \\
1.6 \times 10^{3} \\
2.3 \times 10^{3} \\
4.1 \times 10^{3} \\
4.0 \times 10^{3} \\
2.0 \times 10^{3} \\
1.6 \times 10^{4} \\
1.0 \times 10^{2} \\
3.0 \times 10^{2} \\
4.2 \times 10^{2} \\
1.6 \times 10^{3} \\
1.0 \times 10^{1} \\
2.1 \times 10^{4} \\
2.0 \times 10^{3} \\
1.4 \times 10^{4} \\
1.8 \times 10^{3} \\
2.0 \times 10^{4}\end{array}$ & $\begin{array}{l}5.4 \times 10^{5} \\
3.1 \times 10^{4} \\
2.4 \times 10^{4} \\
1.8 \times 10^{5} \\
3.0 \times 10^{5} \\
7.2 \times 10^{4} \\
1.7 \times 10^{5} \\
1.8 \times 10^{5} \\
1.5 \times 10^{5} \\
4.9 \times 10^{5} \\
1.3 \times 10^{4} \\
3.1 \times 10^{4} \\
5.2 \times 10^{4} \\
7.5 \times 10^{4} \\
1.2 \times 10^{4} \\
1.5 \times 10^{5} \\
1.8 \times 10^{5} \\
1.3 \times 10^{5} \\
1.5 \times 10^{5} \\
2.0 \times 10^{5}\end{array}$ \\
\hline 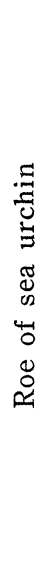 & $\begin{array}{l}U-1^{a)} \\
U-2^{a)} \\
U-3 \\
U-4^{a)} \\
\left.U-5^{a}\right) \\
\left.U-6^{a}\right) \\
\left.U-7^{a}\right) \\
U-8^{a)} \\
\left.U-9^{a}\right) \\
U-10^{a)} \\
U-11 \\
U-12^{a)} \\
U-13 \\
U-14 \\
U-15 \\
U-16^{a)} \\
U-17^{a)} \\
U-18 \\
U-19^{a)} \\
U-20\end{array}$ & $\begin{array}{r}15 \\
10 \\
10 \\
15 \\
15 \\
17 \\
16 \\
16 \\
16 \\
13 \\
6 \\
6 \\
3 \\
7 \\
3 \\
3 \\
2 \\
17 \\
10 \\
10\end{array}$ & $\begin{array}{l}3 \\
2 \\
2 \\
2 \\
2 \\
2 \\
2 \\
2 \\
4 \\
3 \\
3 \\
3 \\
- \\
- \\
- \\
- \\
2 \\
4 \\
-\end{array}$ & $\begin{array}{l}7.6 \times 10^{4} \\
1.2 \times 10^{4} \\
2.6 \times 10^{2} \\
4.1 \times 10^{5} \\
3.5 \times 10^{5} \\
3.0 \times 10^{2} \\
2.4 \times 10^{4} \\
1.9 \times 10^{3} \\
3.3 \times 10^{3} \\
3.9 \times 10^{5} \\
1.1 \times 10^{5} \\
2.2 \times 10^{3} \\
1.4 \times 10^{5} \\
7.1 \times 10^{5} \\
3.2 \times 10^{5} \\
2.2 \times 10^{3} \\
6.1 \times 10^{3} \\
1.7 \times 10^{5} \\
4.1 \times 10^{5} \\
2.1 \times 10^{6}\end{array}$ & $\begin{array}{l}1.3 \times 10^{5} \\
1.8 \times 10^{4} \\
1.9 \times 10^{3} \\
3.1 \times 10^{4} \\
3.2 \times 10^{4} \\
6.0 \times 10^{2} \\
1.6 \times 10^{4} \\
7.0 \times 10^{2} \\
2.8 \times 10^{4} \\
1.4 \times 10^{4} \\
1.1 \times 10^{5} \\
8.3 \times 10^{3} \\
1.4 \times 10^{5} \\
6.2 \times 10^{5} \\
6.0 \times 10^{5} \\
5.7 \times 10^{3} \\
1.1 \times 10^{4} \\
1.6 \times 10^{5} \\
1.0 \times 10^{7} \\
4.1 \times 10^{6}\end{array}$ & $\begin{array}{l}1.1 \times 10^{5} \\
1.1 \times 10^{5} \\
3.4 \times 10^{3} \\
1.2 \times 10^{6} \\
1.3 \times 10^{6} \\
7.1 \times 10^{4} \\
1.6 \times 10^{4} \\
1.7 \times 10^{3} \\
7.5 \times 10^{3} \\
7.9 \times 10^{4} \\
3.9 \times 10^{4} \\
2.9 \times 10^{3} \\
2.7 \times 10^{3} \\
1.5 \times 10^{5} \\
1.2 \times 10^{6} \\
3.6 \times 10^{3} \\
2.6 \times 10^{3} \\
3.8 \times 10^{4} \\
1.0 \times 10^{7} \\
6.5 \times 10^{5}\end{array}$ \\
\hline
\end{tabular}

a) Samples which fungi were isolated

b) Unknown

c) Temperature at which the samples were stored 
Table 3. Ranges of Microbial Counts of Chilled Raw Seafoods Incubated at 5, 25 and $35^{\circ} \mathrm{C}$.

\begin{tabular}{|c|c|c|c|c|c|c|c|}
\hline \multirow{2}{*}{ Sample } & \multirow{2}{*}{$\begin{array}{l}\text { No. of } \\
\text { sample }\end{array}$} & \multirow{2}{*}{$\begin{array}{c}\text { Type of } \\
\text { organisms }\end{array}$} & \multirow{2}{*}{$\begin{array}{l}\text { Incubation } \\
\text { temp. }\left({ }^{\circ} \mathrm{C}\right)\end{array}$} & \multicolumn{4}{|c|}{$\begin{array}{c}\text { Microbial counts per gram at the } \\
\text { level of }\end{array}$} \\
\hline & & & & $<10$ & $10^{1}-10^{3}$ & $10^{4}-10^{5}$ & $10^{6}-10^{7}$ \\
\hline \multirow{5}{*}{ Roe of sea urchin } & \multirow{5}{*}{20} & Bacteria & 35 & $-\%$ & $8^{\text {a) }} 40 \%$ & 8a) $40 \%$ & 4a) $20 \%$ \\
\hline & & Yeasts & 5 & - & $7 \quad 35$ & 1260 & 15 \\
\hline & & Molds & 5 & $18^{\text {a) }} 90$ & 210 & - & - \\
\hline & & Yeasts & 25 & - & $5 \quad 25$ & $13 \quad 65$ & 210 \\
\hline & & Molds & 25 & 735 & 1260 & 15 & - \\
\hline \multirow{5}{*}{ Slice of raw tuna } & \multirow{5}{*}{20} & Bacteria & 35 & - & - & 20100 & - \\
\hline & & Yeasts & 5 & 420 & 1470 & 210 & - \\
\hline & & Molds & 5 & $17 \quad 85$ & $3 \quad 15$ & - & - \\
\hline & & Yeasts & 25 & 15 & 1575 & 420 & - \\
\hline & & Molds & 25 & 1155 & $9 \quad 45$ & - & - \\
\hline \multirow{5}{*}{ Foot of hen clam } & \multirow{5}{*}{17} & Bacteria & 35 & - & $5 \quad 29$ & \multirow{2}{*}{$\begin{array}{rr}11 \quad 65 \\
-\end{array}$} & \multirow{2}{*}{16} \\
\hline & & Yeasts & 5 & 16 & $16 \quad 94$ & & \\
\hline & & Molds & 5 & $8 \quad 47$ & 953 & - & - \\
\hline & & Yeasts & 25 & 212 & 1588 & - & - \\
\hline & & Molds & 25 & 318 & $14 \quad 82$ & - & - \\
\hline
\end{tabular}

a) Number of samples which the microorganisms were isolated

Table 4. Frequency of Occurrence of Yeasts, Molds and Bacteria in Chilled Raw Seafoods

\begin{tabular}{|c|c|c|c|c|c|c|c|}
\hline \multirow{2}{*}{$\begin{array}{l}\frac{\begin{array}{c}\text { Type of } \\
\text { organisms }\end{array}}{\text { Yeasts }} \\
\text { Y }\end{array}$} & \multirow{2}{*}{$\frac{\begin{array}{l}\text { Incubation } \\
\text { temp. }\left({ }^{\circ} \mathrm{C}\right)\end{array}}{5}$} & \multicolumn{2}{|c|}{$\begin{array}{l}\text { Roe of sea urchin } \\
20^{\mathrm{a})}\end{array}$} & \multicolumn{2}{|c|}{$\begin{array}{l}\text { Slice of raw tuna } \\
20^{\mathrm{a})}\end{array}$} & \multicolumn{2}{|c|}{ Foot of hen clam } \\
\hline & & $20^{b)}$ & $100 \%$ & $16^{\mathrm{b})}$ & $80 \%$ & $16^{\mathrm{b})}$ & $94 \%$ \\
\hline & 25 & 20 & 100 & 19 & 95 & 15 & 88 \\
\hline \multirow{2}{*}{ Molds } & 5 & 2 & 10 & 3 & 15 & 9 & 53 \\
\hline & 25 & 13 & 65 & 9 & 45 & 14 & 82 \\
\hline Bacteria & 35 & 20 & 100 & 20 & 100 & 17 & 100 \\
\hline
\end{tabular}

a) Number of samples tested

b) Number of samples tested which the microorganisms were isolated

Table 5. Frequency of Occurrence of Yeast Genera in Chilled Raw Seafoods Incubated at 5 and $25^{\circ} \mathrm{C}$

\begin{tabular}{|c|c|c|c|c|c|c|c|c|c|c|c|c|}
\hline Sample & \multicolumn{4}{|c|}{$\begin{array}{l}\text { Roe of sea urchin } \\
\left.20^{\mathrm{a}}\right)\end{array}$} & \multicolumn{4}{|c|}{ Slice of raw tuna } & \multicolumn{4}{|c|}{ Foot of hen clam } \\
\hline Incub. temp. & \multicolumn{2}{|c|}{$5^{\circ} \mathrm{C}$} & \multicolumn{2}{|c|}{$25^{\circ} \mathrm{C}$} & \multicolumn{2}{|c|}{$5^{\circ} \mathrm{C}$} & \multicolumn{2}{|c|}{$25^{\circ} \mathrm{C}$} & \multicolumn{2}{|c|}{$5^{\circ} \mathrm{C}$} & \multicolumn{2}{|c|}{$25^{\circ} \mathrm{C}$} \\
\hline Debaryomyces & - & -\% & $2^{b)}$ & $10 \%$ & $4^{b)}$ & $20 \%$ & $1^{b}$ & $5 \%$ & $3^{\text {b) }}$ & $18 \%$ & $1^{b)}$ & $6 \%$ \\
\hline Candida & $11^{b)}$ & 55 & 11 & 55 & 10 & 50 & 13 & 65 & 3 & 18 & 6 & 35 \\
\hline Cryptococcus & 7 & 35 & 7 & 35 & 1 & 5 & 6 & 30 & 3 & 18 & 1 & 6 \\
\hline Rhodotorula & 18 & 90 & 20 & 100 & 10 & 50 & 7 & 35 & 10 & 59 & 12 & 71 \\
\hline Torulopsis & 5 & 25 & 6 & 30 & - & - & - & - & - & - & 1 & 6 \\
\hline Trichosporon & 10 & 50 & 7 & 35 & 5 & 25 & 17 & 85 & 6 & 35 & 8 & 47 \\
\hline Unidentified $A_{1}$ & - & - & - & - & - & - & - & - & 1 & 6 & - & - \\
\hline Unidentified $\mathrm{U}_{1}$ & - & - & 3 & 15 & - & - & 1 & 5 & - & - & 2 & 12 \\
\hline
\end{tabular}

a) Number of samples tested b) Number of samples which the yeasts were isolated 
バカガイでは，酵母の分布はマグロとほぼ同様な傾向 を示したが，糸状菌は $25^{\circ}$ 培養の場合， $82 \%$ の試料から 高頻度に検出された.

\section{1 醰母の分布}

冷蔵鮮魚介類の培養温度別に打ける酵母菌属の出現頻 度を Table 5 に，また菌種レベルでの分布を Table 8 に示した。

生ウニでは $5^{\circ}$ および $25^{\circ}$ 培養での酵母の分布状態 は，ほぼ似ていた.すなわち, Rhodotorula (R. aurantiaca, R. glutinis, $R$. rubra カッユ内の菌種はアルフ アベット順）が，試験試料の $90 \%$ （5 培養）拈よび $100 \%$ (25 培養) の試料から検出され, 次いで Candida (C. beechii, C. lipolytica, C. sake, Candida spp.) ๖ Trichosporon (Tr. cutaneum, Tr. pullulans) が $5^{\circ}$ 和よび $25^{\circ}$ 培養でそれぞれ約半数の試料 に認められた. ほかに Cryptococcus (Cr. albidus, $\mathrm{Cr}$. laurentii, Cr. luteolus, Cr. macerans), Torulopsis candida, Debaryomyces hansenii が検出された.

マグロでは, 生ウ二の場合とは異なり, $5^{\circ}$ と $25^{\circ}$ 培 養に护ける酵母の分布状態が異っていた。すなわち，50 培養では Candida (C. guilliermondii, C. lipolytica, C. solani, C. zeylanoides, Candida sp. $\left.\mathrm{M}_{1}\right)$ ¿ Rhodotorula ( $R$. glutinis, $R$. graminis, R. rubra, $R$. pallida) がそれぞれ半数の試料から, Trichosporon $(T r$. cutaneum, Tr. variabile, Trichosporon sp. $\mathrm{M}_{1}$ ) が 1/4の試料から検出された。 しかし $25^{\circ}$ 培養では, Trichosporon (Tr. cutaneum, Trichosporon sp. $\mathrm{M}_{1}$ ) が最 優勢であり, 試験 20 試料のうち 17 試料から $85 \%$ の 高頻度で検出された. 次いで Candida (C. guilliermondii, C. humicola, C. lipolytica, C. zeylanoides, Candida sp. $\left.\mathrm{A}_{1}\right)$ が 13 試料 (65\%) から, Rhodotorula (R. glutinis, R. graminis) が 7 試料 $(35 \%)$ から, Cryptococcus (Cr. albidus, Cr. infirmo-miniatus, $\mathrm{Cr}$. laurentii) が 6 試料 (30\%) から，それぞれ検出された.

バカガイでは Rhodotorula (R. glutinis, R.graminis) が $25^{\circ}$ 培養で 12 試料 $(71 \%)$ から， $5^{\circ}$ 培養では 10 試 料 $(59 \%)$ から検出され，最も優勢であった. Trichosporon (Tr. cutaneum, Tr. pullulans) は $5^{\circ}$ 培養では 6 試料 (35\%) から, $25^{\circ}$ 培養では 8 試料 (47\%) から検 出され, 生ウ二の場合と培養温度での差はあるが, ほぼ 同様な出現頻度を示した. Candida (C. parapsilosis, Candida spp.) の出現頻度は生ウニより低かった.

\section{2 糸状菌の分布}

冷蔵鮮魚介類の培養温度別に和ける系状菌属の出現頻 度を Table 6 に示した。

生ウ =の $5^{\circ}$ 培養では, Cladosporium と Penicillium の 2 属が出現したにすぎないが，これに対して $25^{\circ}$ 培養では出現菌属が多く, Acremonium, Aureoba-

Table 6. Frequency of Occurrence of Fungal Genera and Fungal Counts in Chilled Raw Seafoods Incubated at 5 and $25^{\circ} \mathrm{C}$

\begin{tabular}{|c|c|c|c|c|c|c|c|c|c|c|c|}
\hline Sample & \multicolumn{3}{|c|}{ Roe of sea urchin, $20^{a}$ ) } & \multicolumn{4}{|c|}{ Slice of raw tuna, $\left.20^{a}\right)$} & \multicolumn{4}{|c|}{ Foot of hen clam, $17^{\mathrm{a}}$} \\
\hline Incub. temp. & $5^{\circ} \mathrm{C}$ & \multicolumn{2}{|c|}{$25^{\circ} \mathrm{C}$} & \multicolumn{2}{|c|}{$5^{\circ} \mathrm{C}$} & \multicolumn{2}{|c|}{$25^{\circ} \mathrm{C}$} & \multicolumn{2}{|c|}{$5^{\circ} \mathrm{C}$} & \multicolumn{2}{|c|}{$25^{\circ} \mathrm{C}$} \\
\hline Genus & b) $\%$ counts & b) $\%$ & counts $/ g$ & b) $\% \mathrm{c}$ & ints $/ g$ & b) $\% \mathrm{c}$ & $\mathrm{ts} / \mathrm{g}$ & b) $\% \mathrm{cc}$ & $\mathrm{ts} / \mathrm{g}$ & b) $\% \mathrm{c}$ & $\mathrm{ts} / \mathrm{g}$ \\
\hline Acret & --- & 15 & $501-5000$ & -- & - & 210 & $1-100$ & 16 & $1-100$ & 16 & $101-500$ \\
\hline Alte & --- & -- & - & -- & - & 15 & $1-100$ & -- & - & - - & - \\
\hline Aspers & --- & -- & - & -- & - & 15 & $01-500$ & -- & - & 16 & $1-100$ \\
\hline Aureobasic & --- & 15 & $101-500$ & -- & - & 15 & $1-100$ & 16 & $1-100$ & 212 & $101-500$ \\
\hline Cladosporium & $151-100$ & 315 & $1-\quad 100$ & -- & - & 210 & $1-100$ & 16 & $01-500$ & 530 & $101-500$ \\
\hline Coniothyrium & --- & - - & - & -- & - & -- & - & 16 & $1-100$ & 16 & $1-100$ \\
\hline Fusarium & --- & 210 & $1-\quad 100$ & - - & - & 210 & $1-100$ & 16 & $1-100$ & 424 & $101-500$ \\
\hline Geotrichum & --- & - & - & 15 & $01-500$ & - - & - & 16 & $1-100$ & 16 & $1-100$ \\
\hline Gliomastix & --- & 15 & $501-5000$ & - - & - & -- & - & -- & - & -- & - \\
\hline Mucor & --- & 15 & $5001-50000$ & 15 & $1-100$ & -- & - & -- & - & -- & - \\
\hline Paecilomyces & --- & -- & - & -- & - & -- & - & -- & - & 16 & $101-500$ \\
\hline Penicillium & $151-100$ & 840 & $501-5000$ & 210 & $1-100$ & 210 & $1-100$ & 318 & $1-100$ & 318 & $1-100$ \\
\hline Pestalotia & --- & 15 & $1-\quad 100$ & -- & - & -- & - & -- & - & -- & - \\
\hline Phoma & --- & 15 & $1-\quad 100$ & -- & - & 210 & $1-100$ & 212 & $01-500$ & 16 & $1-100$ \\
\hline Trichoderma & $-\ldots$ & 15 & $1-\quad 100$ & - & 一 & -- & - & 16 & $01-500$ & 16 & $1-100$ \\
\hline
\end{tabular}

a) Number of samples tested

b) Number of samples which the fungi were isolated 
Table 7. Frequency of Occurrence of Bacterial Genera in Chilled Raw Seafoods Incubated at 5,25 or $35^{\circ} \mathrm{C}$

\begin{tabular}{|c|c|c|c|c|c|c|}
\hline Genus & \multicolumn{2}{|c|}{$\begin{array}{l}\text { Roe of sea urchin } \\
20^{\text {a) }}\end{array}$} & \multicolumn{2}{|c|}{$\begin{array}{l}\text { Slice of raw tuna } \\
20^{\mathrm{a})}\end{array}$} & \multicolumn{2}{|c|}{ Foot of hen clam } \\
\hline Aerococcus & $2^{b)}$ & $10 \%$ & $2^{\text {b) }}$ & $10 \%$ & $-b)$ & $-\%$ \\
\hline Acinetobacter & - & - & 2 & 10 & - & - \\
\hline Alkaligenes & - & - & - & - & 5 & 30 \\
\hline Bacillus & 4 & 20 & 1 & 5 & 4 & 24 \\
\hline Chromobacterium & 2 & 10 & - & - & - & - \\
\hline Citrobacter & 1 & 5 & 1 & 5 & - & - \\
\hline Corynebacterium & 6 & 30 & 3 & 15 & 3 & 18 \\
\hline Enterobacter & 3 & 15 & 1 & 5 & - & - \\
\hline Escherichia & - & - & 2 & 10 & - & - \\
\hline Flavobacterium & - & - & - & - & 1 & 6 \\
\hline Micrococcus & - & - & 4 & 20 & 1 & 6 \\
\hline Pseudomonas & 2 & 10 & 9 & 45 & 4 & 24 \\
\hline Staphylococcus & 3 & 15 & 4 & 20 & 7 & 42 \\
\hline
\end{tabular}

a) Number of samples tested

b) Number of samples which the bacteria were isolated

sidium, Mucor, Pestalotia などの 10 属が認められた. マグロの $5^{\circ}$ 培養では Penicillium, Mucor, Geotrichum の 3 属が, $25^{\circ}$ 培養では Alternaria, Asper. gillus, Fusarium などの 8 属が分離された.

バカガイでは，生ウニやマグロの場合と異なり，低温 培養に执いても多くの糸状菌が検出され， $5^{\circ}$ 培養では Phoma, Coniothyrium などの 9 属が，250 培養では Aureobasidium, Trichoderma などの 11 属が検出さ れた。

\section{3 細菌の分布}

冷蔵鮮魚介類に拈ける一般細菌の出現頻度を属のレベ ルで Table 7 に示した.

生ウ二では,グラム陽性桿菌 (Corynebacterium, Bacillus) とグラム陰性桿菌 (Enterobacter, Pseudo. monas, Chromobacterium, Citrobacter) が, ほぼ同じ 頻度で出現した.この活かにグラム陽性球菌 (Staphylococcus, Aerococcus) が検出された.

マグロに拈ける出現菌属の順位は生ウニとは異って拉 り, グラム陰性桿菌 (Pseudomonas, Acinetobacter, Escherichia, Enterobacter, Citrobacter) が最優勢であ った.グラム陽性球菌 (Staphylococcus, Micrococcus, A erococcus) がこれに続いたが, グラム陽性桿菌 (Corynebacterium, Bacillus) は低い分布率を示した.

バカガイでは, マグロと同様にグラム陰性桿菌 (Pseudomonas, Alcaligenes, Flavobacterium), グラム陽性 球菌 (Staphylococcus, Micrococcus), グラム陽性桿菌 (Bacillus, Corynebacterium) の順であった.

\section{4. 生菌数と微生物フローラとの関係}

冷蔵鮮魚介類に和ける培養温度別の微生物フローラを
Table 8 に示した. 生ウニ, マグロ, バカガイの各代表 2 試料について生菌数と微生物フローラの関係を検討 した.

生ウニ u-1 は, アラスカから殼付で輸入したものを宮 城県で加工し, 東京都中央卸売市場へ輸送し, その後当 所に搬入した。この間 3 日を要し, 試料採取時の保管温 度は $15^{\circ}$ であった. $5^{\circ}$ 培養での酵母数は $7.6 \times 10^{4}$ で, R. rubra, Cr. laurentii, Candida $\mathrm{sp} . \mathrm{U}_{3}$ が主要分布 酵母であったが，前報 ${ }^{23)} に$ 記載したと同様な $37^{\circ}$ で生育 する病原酵母と同種の Tr. cutaneum が $5 \%$ の割合で存 在していた. $25^{\circ}$ 培養での酵母数および酵母フローラは $5^{\circ}$ 培養の場合と注とんど同様な傾向を示した．細菌 数は $1.1 \times 10^{5}$ であり，このうち紫色素を産生し，糖を 酸化的に分解する水由来の低温細菌 Chromobacterium が95\%,このほか Aerococcus, Staphylococcus, Bacillus などが分離された，系状菌はPenicillium が $10^{3}$ 検出 された。

生ウニ u-19 は北海道産である. 産地からトラックで 卸市場に輸送し, 東京都内の百貨店経由で当所に搬入，

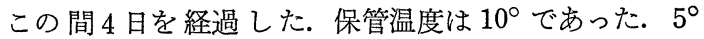
培養での酵母数は $4.1 \times 10^{5}, 25^{\circ}$ 培養では 2 オーダー 高く, $1.0 \times 10^{7}$ となっており，いずれの場合にも $R$. rubra が $60 \%$, D. hansenir が $40 \%$ の 2 菌種で構成

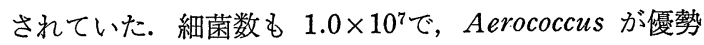
菌であった．糸状菌は低温性の Mucor が $5.0 \times 10^{4}$ の 高い菌数で検出され, 分離の際, 平板全面を括括ってし まら状態であった。

マグロ M-4 は漁獲水域不明のメバチマグロの刺身で ある。東京都中央卸売市場から東京都内の百貨店経由で 


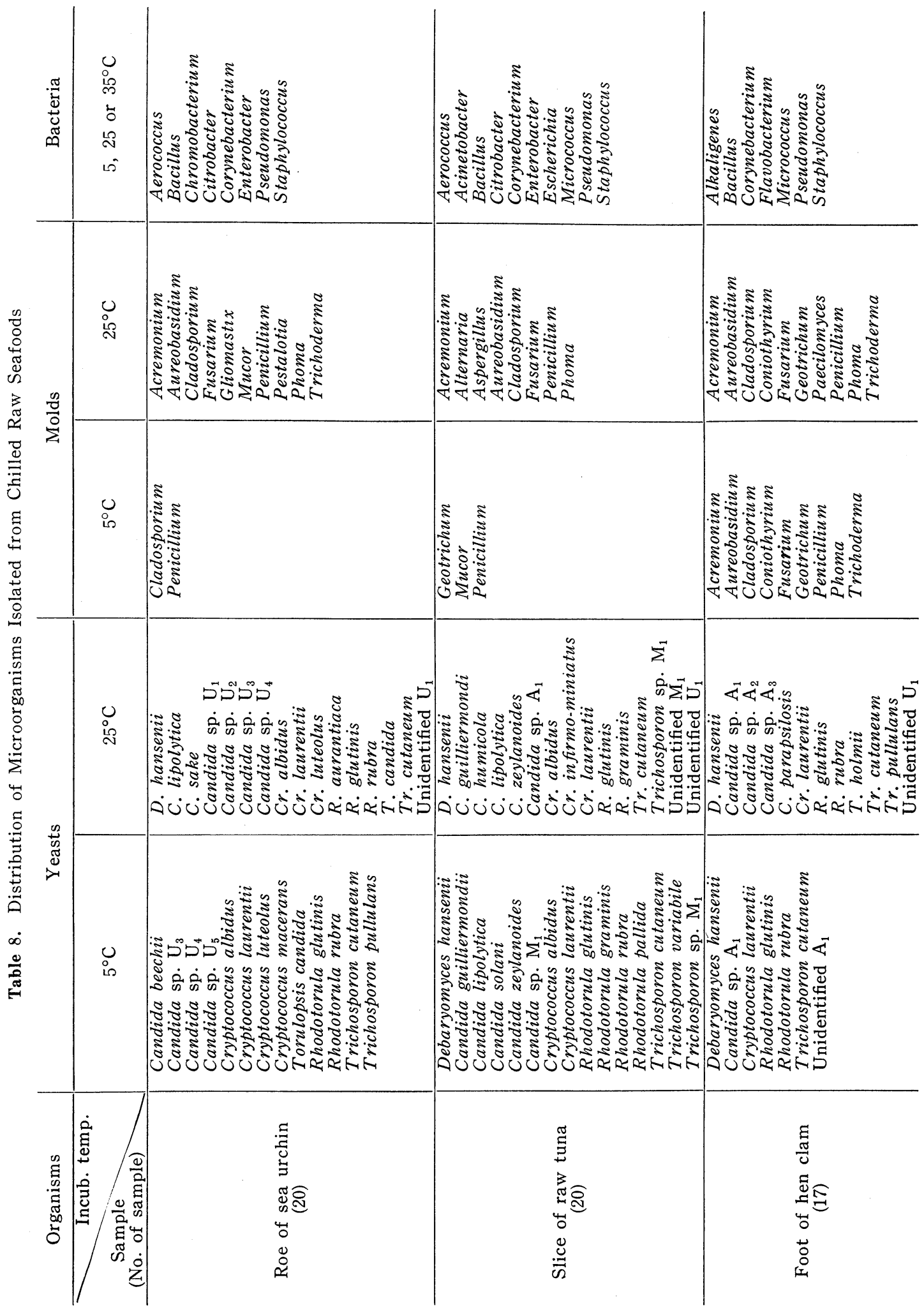


当所に搬入した。保管温度は 2〜 90 であった. $5^{\circ}$ 培養 での酵母数は $10^{1}$ 以下であったが, $25^{\circ}$ 培養では $4.2 \times$ $10^{3}$ で C. lipolytica が優勢であった. ほかに Cr. in. firmo-miniatus と前述の Tr. cutaneum が 10\% の割 合で分布していた， 細菌数は $1.8 \times 10^{5}$ で, Pseudomonas, Micrococcus, Staphylococcus が検出されたが，系 状菌は検出されなかった。

マグロ M-10 はホンマグロの刺身である. 仲買, 東京

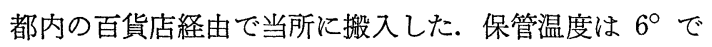
あった. $5^{\circ}$ 培養での酵母数は $1.8 \times 10^{4}$ で, C. guilliermondii, $R$. glutinis 之前述の Tr. cutaneum が認 められた. $25^{\circ}$ 培養での酵母数抢よび酵母フローラは $5^{\circ}$ 培養の場合とほぼ同様な傾向を示した，細菌数は $7.9 \times$ $10^{4}$ で Pseudomonas, Enterobacter, Citrobacter, Acinetobacterなどグラム陰性細菌が優勢であり，あと Staphylococcus が $10^{3}$ のオーダーで検出された. 糸状 菌は Alternaria, Cladosporium が $10^{2}$ 以下の菌数で 検出された.

バカガイA-8 は千葉県産であり, 加工は千葉県内で行 った. 東京都中央卸売市場経由で当所に搬入したが，こ の間 3 日を経過し, 試料採取時の保管温度は $10^{\circ}$ であっ た. 酵母は主として R. rubra が $10^{2}$ のオーダーで，ま た細菌は Alcaligenes, Corynebacterium が $10^{6}$ のオー ダーで検出された. 系状菌数は $10^{2}$ 以下であったが, $5^{\circ}$ 培養で Coniothyrium, $25^{\circ}$ 培養で Paecilomyces, Peni. cillium, Aspergillus, Trichoderma の 5 属が分離され た.

バカガイ A-11 は香川県産のものを千葉県で加工し, 保冷車により市場経由で当所まで約 20 時間で輸送した。 この際, 検体は氷蔵されていた. 酵母数は少なく, $5^{\circ}$ 培 養では $5.0 \times 10^{1}, 25^{\circ}$ 培養では $1.0 \times 10^{2}$ で, D. hansenii, R. rubra, Tr. pullulans が認められた. 糸状菌 は検出されなかったが, 細菌数は $7.5 \times 10^{3}$ で Bacillus, Corynebacterium, Staphylococcus が検出された.

\section{5. 分離酔母および糸状菌の生育温度の㭘討}

冷蔵鮮魚介類から分離した酵母 37 菌種のらち, $5^{\circ}$ で 2 週間以内に生育する低温酵母 ${ }^{233}$ は 35 菌種 (94.6\%), 分離糸状菌 40 株のらち低温系状菌は 22 株 $(55.0 \%)$ で あった。これらの菌株は $20^{\circ}$ でも生育した。

\section{考察}

バカガイおよびマグロ刺身, 生ウニの 3 種市販冷藏鮮 魚介類の一般細菌数は $1 \mathrm{~g}$ 当たり $10^{3} \sim 10^{7}$ の範囲にあり, 相磯ら ${ }^{10)}$ の刺身の細菌数測定結果 $10^{4} \sim 10^{6}$ とほぼー一致 した. 今回の細菌フローラ検索の実験条件では魚介類特 有の低温域に叔ける細菌を検出することはできなかった

*1 川口信行: 山口県衛生研究所, 私信 (1977).

$* 2$ 関利仁ら：日本医真菌学会 総会講演要旨集, p. 33 (1979).

*3 森田豊寿: 日本赤十字社医療センター, 私信(1977).
が，魚介類の腐敗細菌であるPseudomonasなどのグラ ム㓌性桿菌を多く検出して抒り，このほかグラム陽性の 球菌と桿菌を分離したことは, 従来の細菌学的調查報告 と大差はなかったようである。著者らは，このような鮮 魚介類の細菌污染状況をは握した上で, 細菌以外の微生 物，すなわち酵母と糸状菌による污染の実態を総合的に 検討したが，まず酵母について考えてみる．調查の結 果, 酵母は冷蔵鮮魚介類中に主要な微生物群として存在 して拈り，その酵母フローラは 6 属 33 種に及んでいる ことがわかった。

魚介類のミクロフローラは海水のそれと関係が深いと いわれている(1). Morris ${ }^{24)}$ は, 海水には D. hansenii, Cr. albidus, Cr. laurentii, C. parapsilosis, C. guilliermondii, C. tropicalis, T. famata, R. mucilaginosa などの酵母が存在していることを報告している が，著者らも 3 種鮮魚介類から上記のD. hansenii 以下 5 種の酵母を分離して抢り，興味深い結果であった。海 産物の酵母フローラについては Ross ら ${ }^{18)}$ の報告があ る.これによるとスコットランド近海とアイスランド漁 場で獲れた水揚直後, または市販の魚の $80 \%$ に酵母が 認められ，これらの酵母は魚のふんや兄らよりも表皮に 多く分布していたことが述べられている，它の酵母フロ 一ラは D. hansenii が $47.7 \%$ の検出率で最も高く, T. inconspicua $(12.8 \%)$, C. parapsilosis $(10.1 \%)$ など が検出されている．著者らが調查した鮮魚介類の䤉母フ ローラは Ross らの結果とは異なっており, D. hansenii に代って Rhodotorula が最優勢であった. また Ross らが分離しなかった Trichosporon を著者らは多 く分離した. Trichosporon 属のうち，Tr. inkin ${ }^{25)}$ と Tr. cutaneum ${ }^{26)}$ の 2 菌種は皮膚真菌症疾患部よりしば しば検出される opportunistic pathogen 27) である. 後 者については前報23)ですでに述べたが，著者らは最近我 が国に括ける頭部*1 和よび頓部*2 の皮膚疾患, ツメの炎 症*3などの患部から分離した酵母の同定を依頼され，菌 学的な検索を行ったところ, これらはいずれも $T r$. cutaneum であった. 今回の試料から分離した $37^{\circ}$ で 生育可能な $T r$. cutaneum は生ウ=の 4 試料 $(20 \%)$ から, バカガイの 3 試料 (17.5\%) から,さらにマグロで は 9 試料から $45 \%$ の高頻度で検出された。このほか本 菌は, かに肉 ${ }^{19}$, 冷凍のサケ拈よびイカ22), 新鮮な小エ ビ17，市販かまぼこ ${ }^{21)}$ な゙の水産食品から分離されてお り，分布は比較的広い範囲に及んでいるように思われ る. 日本人が好んで生食に用いる鮮魚介類に, 疾患部か ら分離される菌株と同種の酵母が存在していることは, ヒトの健康に影響を及洔す拈乞れがないとはいえない。 今後の研究が必要と思われる。

糸状菌調查の結果，マグロとバカガイからは広範团の 菌が少量ずつ, また生ウニからは特定菌が多数検出され, 系状菌要注意のものが数試料に認められた. 宇田川ら 283 
のマグロ，サケ，エビなどの冷凍水産食品についての成 績によると， $5^{\circ}$ 培養での糸状菌数は $1 \mathrm{~g}$ 当たり $10^{2}$ 以 下， $25^{\circ}$ 培養では $10^{3} \sim 10^{4}$ であり，低温菌数は $1 \mathrm{~g}$ 当 たり $10^{2}$ 以下, $25^{\circ}$ 培養では $10^{3} \sim 10^{4}$ であり, 低温培養 時より常温培養時に高い值を示した。 その主な糸状菌つ ローラは Penicillium, Phoma, Cladosporium, Aspergillus などであり, 低温糸状菌として Penicillium, Mucor, Phoma が検出されたと述べている. 著者らの 結果も宇田川らの結果と同様な傾向を示していた.

今回の鮮魚介類 57 試料は産地から当所までの流通経 路および輸送方法，販売方法などが明確なものを用い た. 試料は水揚げから4 日以内に当所に搬入されたが, この間常温に放置される場合が多々あり, サンプリング 時の温度もチルド食品の温度帯の上限である $5^{\circ}$ を越え るものが $54.4 \%$ の試料に認められた。このような条件 下で試験された 3 種鮮魚介類は大腸菌群, ブドウ球菌な どの細菌のみならず病原酵母と同種の Tr. cutaneum やC. parapsilosis, また下水污染之関係のある Fusarium ${ }^{29), 30)}$ や低温糸状菌 Mucor, Penicillium, Phoma などの 3 種微生物群によって相当污染されていることが 確認された.

分離酵母の $94.6 \%$ は $5^{\circ}$ で 2 週間以内に生育する低 温酵母であったが，これらの酵母は $20^{\circ}$ でも良好な生育 を示した，酵母の至適生育温度は，ほぼ $20^{\circ}$ 前後であ るため今回のような保管温度の範团 $\left(-10^{\circ} \sim+17^{\circ}\right)$ に ある試料では，酵母の増殖を抑制することは不可能であ る.したがって流通期間中に，生ウニでは最高 $10^{7}$ のオ ーダーまで増殖したものと考えられる，以上の結果から 明らかなように，鮮魚介類を $5^{\circ}$ 以上の温度に放置する ことは即 “酵母の増殖”につながるので，著者らは $5^{\circ}$ 以下の低温管理を強く要望する.すでに国際冷凍協会 ${ }^{31)}$ では 5〜6 日以下の輸送の場合は $5^{\circ}$ 以下, $-1 \sim 1^{\circ}$ が 望ましいと述べており，また厚生省環境衛生局長通達 ${ }^{32}$ の生食用魚介類指導要領に打いても水揚より消費まで50 以下の低温に保存することが望ましいとしている．この ような通達にもかかわらず，実際に調査した保管温度は $5^{\circ}$ を越える試料が多く，微生物による污染も著しかっ た. したがって流通過程での厳重な低温管理および衛生 管理に留意し; 微生物による污染を最少限にとどめるよ ら努力したい.

\section{要 約}

市販冷蔵鮮魚介類の酵母・細菌・系状菌の生菌数を測 定し, これら 3 種微生物群の分布状沉, 低温での生育に ついて検討した結果，以下の知見を得た。

1. 生ウ二の酵母数㧊よび一般細菌数は $10^{4} \sim 10^{7} / \mathrm{g}$ を示す試料が多く，系状菌数は $10^{4}$ 以下であった. マグ 口の酵母数は生ウニより低く $10^{1} \sim 10^{4}$, 一般細菌数は $10^{4} \sim 10^{5}$, 糸状菌数は $10^{2}$ 以下であった. バカガイの酵母 数は $10^{1} \sim 10^{3}$, 一般細菌数は $10^{3} \sim 10^{6}$, 糸状菌数は $10^{2}$
以下であった。.

2. 3 種微生物群の出現頻度は, 生ウニでは酵母が細 菌よりやや優勢であり，マグロとバカガイでは，酵母は 細菌に次ぐ微生物群であった．糸状菌の出現頻度は低か ったが，生ウニとバカガイに糸状菌要注意の試料が認め られた。

3. 3 種鮮魚介類に括ける微生物の分布は, 酵母では Rhodotorula, Candida, Trichosporon, Cryptococcus などの無胞子酵母が, 糸状菌ではPenicillium, Phoma, Cladosporium，Fusarium などがまた細菌では Pseudomonas, Enterobacter などのグラム陰性桿菌や Staphylococcus Bacillus などが主要なものであった.

4. 分離酵母の $94.6 \%$ は $5^{\circ}$ で, 2 週間以内に生育 する低温酵母であり，分離糸状菌の $55.0 \%$ は低温糸状 菌であった。これらの菌株は $20^{\circ}$ でも生育した。

5. 病原酵母と同種の $37^{\circ}$ で生育可能な Trichosporon cutaneum が, 生ウ $=20$ 試料中 4 試料 (20\%) か ら，バカガイ 17 試料中 3 試料 $(17.5 \%)$ から, マグロで は 20 試料中 9 試料から $45 \%$ の高頻度で検出された。

本研究は, 厚生省の「食品規格基準設定のための試験 検査費」の一部により行われたものであり, 試料の収集 に関して多くの都道府県衛生部担当官をわずらわせた. また，味の素(株)中央研究所の中瀬 崇博士に有益な御 助言を賜った．以上の諸氏らに対し，心から感謝の意を 表します．な挔本研究の要旨は，日本食品衛生学会第34 回学術講演会 (1977 年 10 月, 岐阜) に拈いて発表した.

\section{文献}

1) 堀江 進: 食衛誌. 7, 99 104 (1966).

2) 谷口忠敬, 銭谷武平：同上, 10, 266 271 (1969).

3) 持永泰輔: 同上, 2, 75 78 (1961).

4）藤原喜久夫，芦野和子，河野美弥子：同上, 13, 392 397 (1972).

5) Shewan, J. M., Hobbs, G., Hodgkis, W.: J. appl. Bacteriol., 23, 379 390 (1960).

6) Lerke, P., Adams, R., Farber, L.: Appl. Microbiol., 13, 625 630 (1965).

7) Adams, R., Farber, L., Lerke, P.: ibid., 12, 277 279 (1964).

8) Chai, T., Chen, C., Rosen, A., Levin, R. E.: ibid. 16, 1738 1741 (1968).

9）相磯和嘉監修: “食品微生物学”, p. 245 330 (1976) 医歯薬出版 (株).

10) 相磯和嘉: 食衛誌. 1, 12 17 (1960).

11）堀江 進，奥積昌世，木村正幸，赤堀正光，川前 政幸：同上, 13，410４17 (1972).

12）奥積昌世，堀江 進，木村正幸，赤堀正光，川前 政幸：同上，13，418４21 (1972).

13）奥積昌世，堀江 進，木村正幸，赤堀正光，川前 政幸: 同上, 14, 81 89 (1973). 
14) Fischer, B.: Ergebnisse der Plankton-Expedition der Humboldt-Stiftung, 4, 1 83 (1894) 文献 17) 上り引用.

15) Hunter, A.C.: U.S. Dept. Agri. Bulı. No. 819, 1 24 (1920).

16) Snow, J.E., Bread, P. J.: Food Res., 4, 563 585 (1939).

17) Phaff, H. J., Mrak, E. M., Williams, O. B.: Mykologia. 44, 431 451 (1952).

18) Ross, S. S., Morris, E. O.: J. Appl. Bacteriol. 28 (2), 224 234 (1965).

19) Erklund, M., Spinelli, J., Miyauchi, D., Dassow, J.: J. Food Sci., 31, 424 431 (1966).

20) 銭谷武平: 九大農学芸雑誌. 12, 383〜390 (1952).

21）福島 清, 中瀬 崇, 駒形和男：日水誌. 33, 763 $\sim 768$ (1967).

22）駒形和男, 中瀬 崇: 食衛誌. 8, 53 57 (1967).

23）小畠満子, 倉田 浩: 同上, 21, 189 196 (1980).

24) Morris, E. O.: J. appl. Bacteriol., 38, 211
223 (1975).

25) Lodder, J. ed.: "The Yeasts, A Taxonomic Study", p. 1337 1342 (1970), 2nd ed., NorthHolland Publ. Co., Amsterdam.

26) Lodder, J. ed.: ibid., p. 1321 1333 (1970).

27) Male, O.: Contr. Microbiol. Immunol., 3, 66 $\sim 80$ (1977).

28）宇田川俊一，一戸正勝，谷口貞子，高鳥浩介，倉 田 浩: 衛生試報. 93, 142 145 (1975).

29）一言 広, 諸角 聖, 和宇慶朝昭, 善養寺浩: 都 衛研, 研究年報. 24 別冊, $41 \sim 46$ (1972).

30) Booth, C.: "The Genus Fusarium". p. $70 \sim 72$ (1971), Commonwealth Mycological Institute, Kew.

31）食品低温流通推進協議会編：“食品の低温管理”, p. 57 59 (1975). 農林統計協会.

32）食品低温流通 推進協議会編：同上, p. 86 89 (1975) . 